University of Wollongong

Research Online

Australian Institute for Innovative Materials -

Papers

Australian Institute for Innovative Materials

$1-1-2015$

\title{
Mesoporous hierarchical anatase for dye-sensitized solar cells achieving over $10 \%$ conversion efficiency
}

Jianjian Lin

University of Wollongong, j1824@uowmail.edu.au

Yoon-Uk Heo

Pohang University of Science and Technology

Andrew Nattestad

University of Wollongong, anattest@uow.edu.au

Yusuke Yamauchi

University of Wollongong

S X. Dou

University of Wollongong, shi@uow.edu.au

See next page for additional authors

Follow this and additional works at: https://ro.uow.edu.au/aiimpapers

Part of the Engineering Commons, and the Physical Sciences and Mathematics Commons

Research Online is the open access institutional repository for the University of Wollongong. For further information contact the UOW Library: research-pubs@uow.edu.au 


\title{
Mesoporous hierarchical anatase for dye-sensitized solar cells achieving over $10 \%$ conversion efficiency
}

\author{
Abstract \\ Interest in both one-dimensional and hierarchical architectures of metal oxide semiconductors has \\ intensified within the field of materials science over recent years. Herein, a new mesoporous anatase $\mathrm{TiO}_{2}$ \\ architecture that combines these two concepts, as it is composed of individual, high-aspect-ratio, \\ nanoribbon-like components, was synthesized via a facile hydrothermal method without any surfactant or \\ template. An 8.3\% solar-to-electric conversion efficiency was obtained when these structures were used \\ in photoanodes for dye-sensitized solar cells, which are superior to commercial state-of-the-art $\mathrm{TiO}_{2}$ \\ $(6.6 \%)$, due to enhanced dye loading and efficient light scattering. To further improve the light scattering \\ effect, a bi-layer structure was rationally designed (with this architecture as a scattering layer on top of a \\ transparent, $12-\mu \mathrm{m}$-thick layer of nanocrystalline $\mathrm{TiO}_{2}$ ). A high efficiency of $10.3 \%$ was achieved, \\ compared with an efficiency of $8.2 \%$ for the control electrode (optimized transparent/reflective \\ commercial titania paste) with a scattering layer of similar thickness.
}

\section{Keywords}

conversion, 10, over, achieving, cells, efficiency, solar, mesoporous, sensitized, dye, anatase, hierarchical

\section{Disciplines}

Engineering | Physical Sciences and Mathematics

\section{Publication Details}

Lin, J., Heo, Y., Nattestad, A., Yamauchi, Y., Dou, S. Xue. \& Kim, J. (2015). Mesoporous hierarchical anatase for dye-sensitized solar cells achieving over 10\% conversion efficiency. Electrochimica Acta, 153 393-398.

\section{Authors}

Jianjian Lin, Yoon-Uk Heo, Andrew Nattestad, Yusuke Yamauchi, S X. Dou, and Jung Ho Kim 


\title{
Mesoporous Hierarchical Anatase for Dye-sensitized Solar Cells
}

\section{Achieving Over $10 \%$ Conversion Efficiency}

\author{
Jianjian Lin, ${ }^{a}$ Yoon-Uk Heo, ${ }^{b}$ Andrew Nattestad,,${ }^{c}{ }^{*}$ Yusuke Yamauchi, ${ }^{d}$ \\ Shi Xue Dou, ${ }^{a}$ and Jung Ho Kim ${ }^{\text {a, }}$
}

${ }^{\mathrm{a}}$ Institute for Superconducting and Electronic Materials (ISEM), Australian Institute for Innovative Materials (AIIM), University of Wollongong, North Wollongong, NSW 2500, Australia

Tel: +61-2-4298-1420.E-mail: jhk@uow.edu.au

${ }^{\mathrm{b}}$ Graduate Institute of Ferrous Technology, Pohang University of Science and Technology, San 31, Hyoja-Dong, Pohang 790-784, Republic of Korea

${ }^{\mathrm{c} I n t e l l i g e n t ~ P o l y m e r ~ R e s e a r c h ~ I n s t i t u t e ~(I P R I), ~ A R C ~ C e n t r e ~ o f ~ E x c e l l e n c e ~ f o r ~ E l e c t r o m a t e r i a l s ~}$

Science, AIIM, University of Wollongong, North Wollongong, NSW 2500, Australia

Tel: +61-2-4298-1456.E-mail: anattest@uow.edu.au

${ }^{\mathrm{d}}$ World Premier International (WPI) Research Center for Materials Nanoarchitectonics (MANA), National Institute for Materials Science (NIMS), 1-1 Namiki, Tsukuba, Ibaraki 305-0044, Japan

\begin{abstract}
Interest in both one-dimensional and hierarchical architectures of metal oxide semiconductors have intensified within the field of materials science over recent years. Herein, a new mesoporous anatase $\mathrm{TiO}_{2}$ architecture that combines these two concepts, as it is composed of individual, high-aspect-ratio, nanoribbon-like components, was synthesized via a facile hydrothermal method without any surfactant or template. An $8.3 \%$ solar-to-electric conversion efficiency was obtained when these structures were used in photoanodes for dye-sensitized solar cells, which are superior to commercial state-of-the-art $\mathrm{TiO}_{2}(6.6 \%)$, due to enhanced dye loading and efficient light scattering. To further improve the light scattering effect, a bi-layer structure was rationally designed (with this architecture as a scattering layer on top of a transparent, $12-\mu \mathrm{m}$-thick layer of nanocrystalline $\mathrm{TiO}_{2}$ ). A high efficiency of $10.3 \%$ was achieved, compared with an efficiency of $8.2 \%$ for the control electrode (optimized transparent/reflective commercial titania paste) with a scattering layer of similar thickness.
\end{abstract}

Keywords: Mesoporous; Anatase $\mathrm{TiO}_{2}$; one-dimensional; hierarchical architectures; Dyesensitized solar cells 


\section{Introduction}

Since Dye-sensitized Solar Cells (DSCs) were first reported by O'Regan and Grätzel in the early 1990s, they have captured a great deal of both scientific and popular attention due to their reduced energy input, projected low cost, and ease of fabrication in manufacture $[1,2]$. Considerable efforts have been made to improve the energy conversion efficiency by developing or modifying DSC components, such as sensitizers [3-5], photoanodes [6,7], electrolytes [8,9], and counter electrodes [10-12]. As the key element of the DSC device, the $\mathrm{TiO}_{2}$ photoanode, sensitized by a chromophore (whether it be a quantum dot, polypyridil Ru-containing complex, or organic donor-acceptor unit), acts as both a physical support for the sensitizer and a means of charge transport. Photoinjected electrons travel from the $\mathrm{TiO}_{2}$ network to the fluorine doped tin oxide (FTO) substrate by diffusion, but are strongly limited by trapping and detrapping, both within particles and at grain boundaries. This process facilitates carrier recombination within the electrolyte at the surface. Electron transport is limited due to the mesoporous structure, which can hinder higher conversion efficiencies.

One method of improving DSC efficiency is to ensure that the electron diffusion length is greater than the $\mathrm{TiO}_{2}$ film thickness. Highly crystalline (less internal traps) one-dimensional (1D) or 2D nanostructures, such as wires $[13,14]$, tubes $[15,16]$, rods $[17,18]$, belts $[19,20]$, fibers $[21$ 23], and sheets [24,25], have attracted much attention because of their faster electron transport. The probability of charge recombination is reduced in $1 \mathrm{D}$ crystalline nanostructures, as compared to polycrystalline structures which have many grain boundaries. Enhanced electron diffusion length of low-dimensional $\mathrm{TiO}_{2}$ has been demonstrated with vertically aligned $\mathrm{TiO}_{2}$ nanowires and nanotubes synthesized by electrochemical anodization using Ti metal [26-32]. When 1D nanostructures were employed as photoanodes, the recombination rate was 10 times 
slower than for the conventional nanoparticle film [33]. It is, however, more difficult for the liquid electrolyte to penetrate into the $1 \mathrm{D}$ nanostructure than into the nanoparticle network. In addition, many 1D nanostructures suffer from having a lower surface area, which leads to reduced dye loading and light harvesting, and hence lower energy conversion efficiency, $\eta$.

The synthesis of hierarchical architectures with high surface area and efficient light trapping is another route to higher $\eta$ [34-36]. In this work, we present a novel architecture combining these two concepts (one-dimensional and hierarchical structuring) via a facile hydrothermal method, without any surfactant or template. This architecture consists of hierarchical assemblies of high-aspect-ratio nanocrystalline ribbons of anatase $\mathrm{TiO}_{2}$, morphologically resembling a spheres and giving rise to a sea-urchin-like structure. When sensitized by N719 and used as a photoanode in a DSC, along with a $\mathrm{I}_{3}^{-} / \mathrm{I}^{-}$redox mediator-based electrolyte, this system can provide an $\eta$ of $8.3 \%$ under simulated air mass (AM) 1.5 sunlight irradiation, a $26 \%$ improvement compared to commercial state-of-the-art $\mathrm{TiO}_{2}(6.6 \%)$. The higher $\eta$ for this morphology is due to the higher specific surface area, leading to higher dye loading and efficient light scattering. To further improve the light scattering effect, a bi-layer structure was produced (with this architecture as a scattering layer on top of a layer of transparent, 12- $\mu$ m-thick, nanocrystalline $\mathrm{TiO}_{2}$ ). An even higher $\eta$ of $10.3 \%$ was achieved, compared with $8.2 \%$ for the Dyesol electrode (optimized transparent/reflective titania paste) with a scattering layer of $400 \mathrm{~nm}$ $\mathrm{TiO}_{2}$ of similar thickness.

\section{Experimental}

\subsection{Synthesis of Mesoporous Hierarchical Anatase $\mathrm{TiO}_{2}$ (MHAT)}

Acetic acid (AA, ACS reagent, $\geq 99.7 \%$, Sigma-Aldrich) and titanium butoxide (TB, Ti $\left(\mathrm{OCH}_{2} \mathrm{CH}_{2} \mathrm{CH}_{2} \mathrm{CH}_{3}\right)_{4}, 97 \%$, analytical reagent, Sigma-Aldrich) were used without further 
purification. MHAT was prepared via a very simple acid thermal process. Briefly, $1.0 \mathrm{~mL}$ of TB, was added at room temperature to $30 \mathrm{~mL}$ AA solution whilst under stirring (with stirring maintained for $24 \mathrm{~h}$ ). This solution was then transferred to a Teflon lined reactor (Parr Instrument Company, $45 \mathrm{~mL}$ ) and heated to $150{ }^{\circ} \mathrm{C}$ for $12 \mathrm{~h}$. Afterwards, the sample was cooled before being centrifuged and washed with distilled water and ethanol sequentially ( 3 cycles). Following this, the samples were dried at $90{ }^{\circ} \mathrm{C}$ overnight and calcined at $500{ }^{\circ} \mathrm{C}$ for $3 \mathrm{~h}$.

\subsection{Preparation of Photoanodes}

Photoanodes were prepared in a manner similar to that reported previously [37]. Briefly, F: $\mathrm{SnO}_{2}$ glass was cleaned using first soapy water, then acetone and finally ethanol before being dried. A dense $\mathrm{TiO}_{2}$ layer was applied using spray pyrolysis of a titanium (IV) diisoproxide-bisacetylacetonate (75 wt \% in isopropanol, Aldrich) solution (dilution 1:9 in ethanol) at $450{ }^{\circ} \mathrm{C}$. A screen printing paste of the MHAT was prepared using $1.0 \mathrm{~g} \mathrm{TiO}_{2}$ ground in ethanol and water. To this was added $0.167 \mathrm{~mL} \mathrm{AA,} 4 \mathrm{~g}$ terpineol, and $0.5 \mathrm{~g}$ ethyl cellulose (in the form of a $10 \mathrm{wt}$ $\%$ solution in ethanol). Water and ethanol were then removed using rotary evaporation, and the resulting paste was printed using a semiautomatic screen printer and custom patterned $43 \mathrm{~T}$ screen to create $4 \mathrm{~mm} \times 4 \mathrm{~mm}$ electrodes. These were dried at $125^{\circ} \mathrm{C}$ before subsequent layers were deposited in order to realise thicker electrodes. After all the printing steps were complete the electrodes were subjected to an extended sintering process $\left(10 \mathrm{~min}\right.$ at $150{ }^{\circ} \mathrm{C}, 5 \mathrm{~min}$ at 325 ${ }^{\circ} \mathrm{C}, 5 \mathrm{~min}$ at $375{ }^{\circ} \mathrm{C}, 30 \mathrm{~min}$ at $450{ }^{\circ} \mathrm{C}$, then $15 \mathrm{~min}$ at $500{ }^{\circ} \mathrm{C}$ ). Finally, a post-treatment was completed by soaking the electrodes in a $20 \mathrm{mM}$ aqueous solution of $\mathrm{TiCl}_{4}$ (Sigma) for $30 \mathrm{~min}$ at $70{ }^{\circ} \mathrm{C}$ and then resintering $\left(500{ }^{\circ} \mathrm{C}, 30 \mathrm{~min}\right)$.

Dyesol-T, 18NR-T transparent titania paste, and Dyesol-S, WER2-O reflective titania paste, were both obtained from Dyesol (Australia). 
For Dyesol-T $(12 \mu \mathrm{m}) / \mathrm{MHAT}(4 \mu \mathrm{m})$ and Dyesol-T $(12 \mu \mathrm{m}) /$ Dyesol-S $(4 \mu \mathrm{m})$ photoanodes: Dyesol-T $(12 \mu \mathrm{m})$ was cast onto the FTO glass with a blocking layer, before MHAT $(4 \mu \mathrm{m})$ or Dyesol-S (4 $\mu \mathrm{m})$ was further cast onto the Dyesol-T layer.

\subsection{Device assembly}

After cooling to $\leq 110^{\circ} \mathrm{C}$, the photoanodes, described above were dipped in $\mathrm{N} 719$ dye solution (0.5 mM, Solaronix) for $\sim 24 \mathrm{~h}$. The dye solution was mixed with tert-butanol (LR, Ajax Chemicals) and acetonitrile (HPLC, Lab-scan) [1:1 (v/v)]. After this time, the photoanodes were removed from the dye bath and washed in clean acetonitrile before being dried. Counter electrodes were prepared by drilling holes in other pieces of $\mathrm{F}: \mathrm{SnO}_{2}$ glass, to be used as a filling port for introduction of the electrolyte solution. These were then cleaned as per the photoanode, before having a drop of $10 \mathrm{mM} \mathrm{H}_{2} \mathrm{PtCl}_{6}$ solution (in ethanol) applied and smeared. After heating to $400{ }^{\circ} \mathrm{C}$ for $20 \mathrm{~min}$ the electrodes are cooled before being sandwiched together with the photoanode, using a $25 \mu \mathrm{m}$ Surlyn (Solaronix) spacer. These were then affixed together through the application of heat $\left(\sim 120^{\circ} \mathrm{C}\right)$. The electrolyte solution [acetonitrile/valeronitrile (85:15 vol \%), iodine $\left(\mathrm{I}_{2}\right)(0.03 \mathrm{M}), 4$ tertbutylpyridine (4-tBP) $(0.5 \mathrm{M})$, 1-butyl-3-methylimidazolium iodide (BMII) $(0.6 \mathrm{M})$, and guanidinium thiocyanate $(\mathrm{GuSCN})(0.1 \mathrm{M})]$ was injected into the filling port via the vacuum back-filling technique, and the filling port was then closed with a piece of Surlyn laminated to aluminium foil.

\subsection{Characterization}

XRD was employed to examine the crystal structures of the resultant products using an X-ray diffractometer (Bruker Advance, $40 \mathrm{kV}, 30 \mathrm{~mA})(\mathrm{Cu} \mathrm{K \alpha}, \lambda=0.15406 \mathrm{~nm})$ from $5^{\circ}$ to $80^{\circ}(2 \theta)(1$ \%/min), while the morphology was examined by FE-SEM (Megallan 200) and TEM (JEM2100F). The surface area and porosity were examined using Brunauner-Emmet-Teller (BET) 
analysis of nitrogen adsorption-desorption data collected on a Tristar 3030 system (Micrometrics Instrument Corporation), after degassing overnight at $150{ }^{\circ} \mathrm{C}$. Dye desorption experiments were performed by washing the photoanodes in $0.1 \mathrm{M} \mathrm{NaOH}$ solution (1:1 vol ratio water:ethanol). Diffuse reflectance-absorbance spectroscopy of ultraviolet(UV)-visible light was used for investigating the light absorption and scattering properties (Shimadzu UV-3600). A Veeco Dektak 150 Surface Profiler was used for the film thickness measurements. A Keithley 2400 sourcemeter was used for photocurrent density - voltage $(J-V)$ curve measurements, under air mass (AM) 1.5 global $(1.5 \mathrm{G})$ one sun illumination $\left(100 \mathrm{~mW} \mathrm{~cm}^{-2}\right)$. A $300 \mathrm{~W}$ Xe lamp was used for incident photon-to-current quantum conversion efficiency (IPCE) measurements, a monocromator with sorting filters focused on a spot with additional optics. A Keithley 2400 SMU was used for recording the short circuit current response of the devices ( $5 \mathrm{~nm}$ steps). The measured currents were referenced to a calibrated Si photodiode (PECCELL). Electrochemical impedance spectroscopy (EIS) was performed at open circuit under illumination (0.1-1.0 MHz).

\section{Results and discussion}

A low magnification scanning electron microscope (SEM) image of mesoporous hierarchical anatase $\mathrm{TiO}_{2}$ (MHAT), obtained by a facile hydrothermal process, is shown in Figure 1(a). Figure 1(b) [bright-field transmission electron microscope (TEM) image] and Figure 1(c) show the detailed microstructure of MHAT, where it can be clearly seen that the sphere is composed of one-dimensional nanoribbons. The annular dark-field scanning transmission electron microscope (ADF-STEM) image in Figure 1(d) highlights a single sphere, revealing mesoporous structure, which is further confirmed by the nitrogen $\left(\mathrm{N}_{2}\right)$ adsorption/desorption data in Figure 1(e), which shows a type IV isotherm, typical of mesoporous material. BrunauerEmmett-Teller (BET) calculations of specific surface area for Dyesol-T (commercial transparent 
titania paste) and MHAT were performed. The porosity $(P)$ and surface roughness factor $(R)$ were measured for these two samples. It is expected that MHAT should be capable of higher dye loading, because MHAT has a significantly higher specific surface area $\left(115 \mathrm{~m}^{2} \mathrm{~g}^{-1}\right)$ and higher porosity $(65.6 \%)$ than Dyesol-T $\left(74 \mathrm{~m}^{2} \mathrm{~g}^{-1}, 64.2 \%\right)$. The large pores formed in MHAT [see the pore size distribution shown in the inset of Figure 1(e)] are able to provide facile channels for the efficient diffusion of $\mathrm{I}_{3}^{-} / \mathrm{I}^{-}$.

The related selected area electron diffraction (SAED) pattern [inset of Figure 1(b)], along with the high resolution TEM (HRTEM) image [Figure S1(a) in the Supporting Information], combined with the X-ray diffraction (XRD) data [Figure 1(f)] and the Raman spectrum [Figure S1(b)], confirm the formation of anatase $\mathrm{TiO}_{2}$ (JCPDS No. 21-1272).

Here, MHAT was deposited on $\mathrm{F}: \mathrm{SnO}_{2}$ glass and applied as photoanode (sensitized by N719, along with a $\mathrm{I}_{3}^{-} / \mathrm{I}^{-}$redox mediator-based electrolyte) in DSCs. The inset of Figure 2(a) shows the cross-sectional SEM image of the MHAT film with a thickness of $12 \mu \mathrm{m}$. The photocurrent density-voltage $(J-V)$ characteristics curves of DSCs fabricated using Dyesol-T and MHAT were measured at $100 \mathrm{~mW} \mathrm{~cm}^{-2}$, as shown in Figure 2(a). Their photovoltaic performances are summarized in Table SI. The MHAT-based DSCs exhibit a short-circuit photocurrent density $\left(J_{\mathrm{sc}}\right)$ of $13.2 \mathrm{~mA} \mathrm{~cm}^{-2}$, an open-circuit photovoltage $\left(V_{\mathrm{oc}}\right)$ of $0.865 \mathrm{~V}$, a fill factor $(F F)$ of $68 \%$, and an overall energy conversion efficiency $(\eta)$ of $8.3 \%$ under one sun conditions, resulting in a $25 \%$ increase over Dyesol-T. The MHAT-based cell showed improved cell efficiency compared to that of Dyesol-T, due to a simultaneous increase in $J_{\text {sc }}$ and $V_{\text {oc }}$. The $J_{\mathrm{sc}}$, as is well known, is strongly related to the amount of dye loaded on the $\mathrm{TiO}_{2}$ film, which largely depends on the surface area. In general, a larger $J_{\text {sc }}$ can be obtained by a greater amount of dye absorbance, to ensure better harvesting of the incident light. The higher $J_{\mathrm{sc}}$ for the MHAT- 
based device could be mainly attributed to the improved dye loading capacity $\left(5.0 \times 10^{-7} \mathrm{~mol} \mathrm{~cm}^{-}\right.$ ${ }^{2}$ ), due to the hierarchical and mesoporous morphology (consistent with the measured specific surface area and roughness factor results), as well as its good light scattering properties. It should be mentioned here that further investigations of the $V_{\text {oc }}$ between these two devices are still ongoing.

The incident photon to current conversion efficiency (IPCE) spectrum is directly related to the $J_{\mathrm{sc}}$ value measured in the $J-V$ curve, which is, in turn, largely determined by the dye loading, electron transfer, and light scattering. The IPCE value [Figure 2(b)] of the MHAT-based cell was higher than that of Dyesol-T over $400-750 \mathrm{~nm}$, which is consistent with its higher $J_{\mathrm{sc}}$ and $\eta$ as shown in Figure 2(a) and Table 1. The IPCE of the MHAT film is approximately $9 \%$ higher than that of Dyesol-T at the peak of the IPCE curve (at $535 \mathrm{~nm}$ ).

It is well known that higher light scattering ability is an effective way to improve the light harvesting efficiency. The diffused reflection spectra of Dyesol-T and MHAT were collected [inset of Figure 2(b)] to compare the light scattering ability of the $\mathrm{TiO}_{2}$ films. The MHAT film has much higher diffused reflection capability in the visible and near-infrared regions (450-800 $\mathrm{nm})$ than Dyesol-T. This indicates that the incident light was highly scattered due to the larger particle size of MHAT compared to the wavelength of visible light. To better utilize the incident light and further increase device efficiency, the use of a scattering layer is a well-known strategy. The light scattering property of MHAT was compared to that of Dyesol-S (commercially reflective titania paste). As expected, it was found that the MHAT and Dyesol-S films showed high reflection capability across the whole range of 400-800 nm, with the Dyesol-S film having lower performance. In particular, the MHAT film scattered the light (at 600-800 nm) more 
effectively, increasing the efficient path length and, giving photons a higher probability of being absorbed by dye molecules due to the larger particle size of MHAT.

The $\eta$ of the photoelectrode was further enhanced to $10.3 \%$ using MHAT as the scattering layer [Dyesol-T $(12 \mu \mathrm{m}) / \mathrm{MHAT}(4 \mu \mathrm{m}), J_{\mathrm{sc}}=16.2 \mathrm{~mA} \mathrm{~cm}^{-2}, V_{\mathrm{oc}}=0.830 \mathrm{~V}$, and $F F=73.0 \%$ ], due to the significantly enhanced $J_{\text {sc }}$ (increased by $16 \%$ ) of the device, compared with the photoelectrode based on Dyesol-T $(12 \mu \mathrm{m}) /$ Dyesol-S $(4 \mu \mathrm{m})$, which reached $8.2 \%$ [Figure 3(a) and Table SII]. It was found that the amount of dye on the Dyesol-T/MHAT film was $6.2 \times 10^{-7}$ mol cm$~^{-2}$, much higher than that of Dyesol-T/Dyesol-S $\left(3.7 \times 10^{-7} \mathrm{~mol} \mathrm{~cm}^{-2}\right)$. Both films resulted in a reasonably broad IPCE response [Figure 3(b)], with the Dyesol-T/MHAT film giving a higher response across the range of 450-750 $\mathrm{nm}$.

The reason for the increased $F F$ and $J_{\mathrm{sc}}$ was further confirmed by the dark current in the $J-V$ curves. We can see from Figure 3(a) that the onset of the dark current for the Dyesol-T/MHAT device shifts to higher potential, in comparison with the Dyesol-T/Dyesol-S device. The darkcurrent of Dyesol-T/MHAT is smaller than that of Dyesol-T/Dyesol-S at the potential at $0.7 \mathrm{~V}$, implying that the Dyesol-T/MHAT-based device has larger recombination resistance. In addition, the Dyesol-T/MHAT-based device near $V_{\text {oc }}$ shows a slightly increased slope in the $J-V$ curves, becasue the series resistance of the DSCs is reduced. The recombination rate of electrons plays an important role for higher $F F$ in DSCs. Hence, by analyzing the $J$ - $V$ curves, it can be concluded that the reasons for the higher $F F$ in the device with MHAT as scattering layer are that the charge recombination is reduced and the charge transfer is further enhanced.

Electron transfer and recombination was further studied by electrochemical impedance spectroscopy (EIS) [38-42]. Figure 3(c) shows the Nyquist plots for DSCs with the two different photoelectrodes obtained under one sun conditions (with the equivalent circuit shown in the 
inset). Generally, according to the literature [43], three characteristic semicircles can be obtained from the EIS spectra. As shown in the inset of Figure 3(c), $R_{\mathrm{ct} 1}$ at high frequency represents the impedance related to the charge transfer at the counter electrode, while $R_{\mathrm{ct} 2}$ at lower frequency shows the impedance at the interface of $\mathrm{TiO}_{2} / \mathrm{I}_{3}^{-} / \mathrm{I}^{-}$[44]. It should be mentioned here that the arc at the lowest frequency, which is related to the electrolyte diffusion, is overlapped in this study, because (1) the viscosity of the liquid electrolyte is very low; (2) the $\mathrm{I}_{3}{ }^{-}$ion diffusion length is shortened by the thin spacer used ( $25 \mu \mathrm{m}$ Surlyn)]. The smaller $R_{\mathrm{ct} 2}$, compared to that for the Dyesol-T/Dyesol-S-based device, can enhance the photogenerated electron collection from the the Dyesol-T/MHAT surface to FTO substrate. The key electron transport parameters, such as the charge transfer resistance $\left(R_{\mathrm{ct}}\right)$ and the constant phase element $(C P E)$, were estimated by fitting the Nyquist plots using the equivalent circuit in Figure 3(c). The fitting data are given in Figure S2 and Table 2.

Bode phase plots further reveal the electron lifetimes of the two devices. In Figure 3(d), for the Dyesol-T/Dyesol-S-based device, two semicircles were formed, while there is one peak (at high frequency) and one shoulder (at low frequency) for Dyesol-T/MHAT, respectively. The electron lifetime in $\mathrm{TiO}_{2}$ film can be calculated based on the following equation:

$$
\tau=1 /\left(2 \pi f_{\max }\right)
$$

Where $\tau$ refers to the lifetime of the photoelectron from injection to arrival at the FTO substrate. $f_{\max }$ is the maximum frequency which enables the DSCs to achieve higher $\eta$. Electrons in the Dyesol-T/MHAT film have longer $\tau(12.8 \mathrm{~ms})$ than that in the Dyesol-T/Dyesol-S film (6.4 ms) and a faster diffusion rate, because the nanoribbons of MHAT are well-crystallized single crystals (as discussed in Figure 1), which exhibit unhindered diffusion. Electron diffusion time $\left(T_{\mathrm{d}}\right)$ can be calculated based on the following equation: 


$$
T_{\mathrm{d}}=1 /\left(f^{\prime}{ }_{\text {max }}\right)
$$

$f^{\prime}{ }_{\text {max }}$ is the maximum frequency of the second semicircle. From Figure 3(d), the $T_{\mathrm{d}}$ for DyesolT/MHAT film and Dyesol-T/Dyesol-S film is $0.08 \mathrm{~ms}$ and $0.1 \mathrm{~ms}$, respectively. The EIS analysis indicates that with MHAT as the effective scattering layer, the photocurrent collection was significantly improved due to faster electron transportation and efficient electrolyte diffusion, and hence, higher $F F$ was obtained in the Dyesol-T/MHAT-based device.

\section{Conclusions}

In summary, a well-defined mesoporous hierarchical anatase $\mathrm{TiO}_{2}(\mathrm{MHAT})$, has been synthesized via a facile hydrothermal method without any surfactant or template. This architecture has been demonstrated as an effective photoelectrode when employed in a DSC. An $\eta$ of $8.3 \%$ was achieved, which is superior to that of an analogous device using Dyesol-T (6.6 $\%)$. We have demonstrated that this morphology is beneficial to enhanced dye loading and efficient light scattering. A higher $\eta$ of $10.3 \%$ was further achieved when MHAT was used as the light scattering layer [Dyesol-T $(12 \mu \mathrm{m}) / \mathrm{MHAT}(4 \mu \mathrm{m})]$, a considerable improvement over the commercial Dyesol-T $(12 \mu \mathrm{m}) /$ Dyesol-S $(4 \mu \mathrm{m})$ system $(8.2 \%)$. This paves the way for further development of DSCs using the double layer strategy fuelled by nanomaterial innovation.

\section{Acknowledgements}

The work is supported by an Australian Research Council Discovery Project (DP1096546). Dr. Andrew Nattestad would like to thank the Australian Renewable Energy Agency (ARENA) for financial support. 


\section{References}

[1] B. O’Regan, M. Grätzel, A low-cost, high-efficiency solar cell based dye-sensitized colloidal $\mathrm{TiO}_{2}$ films, Nature 353, (1991) 737.

[2] A. Hagfeldt, G. Boschloo, L. Sun, L. Kloo, H. Pettersson, Dye-Sensitized Solar Cells Chem. Rev. 110, (2010) 6595.

[3] S. Mathew, A. Yella, P. Gao, R. Humphry-Baker, B. F. E. Curchod, N. Ashari-Astani, I. Tavernelli, U. Rothlisberger, M. Nazeeruddin, M. Grätzel, Dyesensitized solar cells with 13\% efficiency achieved through the molecular engineering of porphyrin sensitizers, Nature Chem. 6 , (2014) 242.

[4] P. Wang, S. M. Zakeeruddin, J. E. Moser, M. K. Nazeeruddin, T, Sekiguchi, M. Grätzel, A stable quasi-solid-state dye-sensitized solar cell with an amphiphilic ruthenium sensitizer and polymer gel electrolyte, Nature Mater. 2, (2003) 402.

[5] T. Kinoshita, J. T. Dy, S. Uchida, T. Kubo, H. Segawa, Wideband dye-sensitized solar cells employing a phosphine-coordinated ruthenium sensitizer, Nature Photonics. 7, (2013) 535.

[6] C. Y. Jiang, X. W. Sun, G. Q. Lo, D. L. Kwong, J. X. Wang, Improved dye-sensitized solar cells with a ZnO-nanoflower photoanode, Appl. Phys. Lett. 90, (2007) 263501.

[7] F. Lenzmanm, J. Krueger, S. Burnside, K. Brooks, M. Grätzel, D. Gal, S. Rühle, D. Cahen, Surface Photovoltage Spectroscopy of Dye-Sensitized Solar Cells with $\mathrm{TiO}_{2}, \mathrm{Nb}_{2} \mathrm{O}_{5}$, and $\mathrm{SrTiO}_{3}$ Nanocrystalline Photoanodes: Indication for Electron Injection from Higher Excited Dye States, J. Phys. Chem. B 105, (2001) 6347.

[8] A. Yella, H. W. Lee, H. N. Tsao, C. Yi, A, K. Chandiran, M. K. Nazeeruddin, E. W. G. Diau, C. Y. Y, S. M. Zakeeruddin, M. Grätzel, Porphyrin-sensitized solar cells with cobalt (II/III)based redox electrolyte exceed 12 percent efficiency, Science 334, (2011) 629. 
[9] P. Wang, S. M. Zakeeruddin, P. Comte, I. Exnar, M. Grätzel, Gelation of ionic liquid-based electrolytes with silica nanoparticles for quasi-solid-state dye-sensitized solar cells, J. Am. Chem. Soc. 125, (2003) 1166.

[10] K. M. Lee, L. C. Lin, C. Y. Chen, V. Suryanaryayanan, C. G. Wu, Preparation of High Transmittance Platinum Counter Electrode at anAmbient Temperature for Flexible DyeSensitized Solar Cells, Electrochim. Acta 135, (2014) 578.

[11] S. S. Rao, C. V.V.M. Gopi, S.-K. Kim, M.-K. Son, M.-S. Jeong, A. D. Savariraj, K. Prabakar, H.-J. Kim, Cobalt sulfide thin film as an efficient counter electrode for dye-sensitized solar cells, Electrochim. Acta 133, (2014) 174.

[12] Z. Huang, X. Liu, K. Li, D. Li, Y. Luo, H. Li, W. Song, L. Q. Chen, Q. Meng, Application of carbon materials as counter electrodes of dye-sensitized solar cells, Electrochem. Comm. 9, (2007) 596.

[13] C. Xu, J. Wu, U. V. Desai, D. Gao, Multilayer assembly of nanowire arrays for dyesensitized solar cells, J. Am. Chem. Soc. 133, (2011) 8122.

[14] S. Lee, G. S. Han, J.-H. Lee, J.-K. Lee, H. S. Jung, Mesoporous $\mathrm{TiO}_{2}$ nanowires as bifunctional materials for dye-sensitized solar Cells, Electrochim. Acta 74, (2012) 83.

[15] S. Wang, X. Zhou, X. Xiao, Y. Fang, Y. Lin, An Increase in Conversion Efficiency of DyeSensitized Solar Cellsusing Bamboo-Type $\mathrm{TiO}_{2}$ Nanotube Arrays, Electrochim. Acta 116, (2014) 26.

[16] G. K. Mor, K. Shankar, M. Paulose, O. K. Varghese, C. A. Grimes, Use of highly-ordered $\mathrm{TiO}_{2}$ nanotube arrays in dye-sensitized solar cells, Nano Lett. 6, (2006) 215. 
[17] Z. Wang, H. Wang, B. Liu, W. Qiu, J. Zhang, S. Ran, H. Huang, J. Xu, H. Han, D. Chen, G. Shen, Transferable and flexible nanorod-assembled $\mathrm{TiO}_{2}$ cloths for dye-sensitized solar cells, photodetectors, and photocatalysts, ACS Nano 5, (2011) 8412.

[18] B. Liu, E. S. Aydil, Growth of oriented single-crystalline rutile $\mathrm{TiO}_{2}$ nanorods on transparent conducting substrates for dye-sensitized solar cells, J. Am. Chem. Soc. 131, (2009) 3985.

[19] Q. Chen, H. Liu, Y. Xin, X. Cheng, $\mathrm{TiO}_{2}$ nanobelts-Effect of calcination temperature on optical,photoelectrochemical and photocatalytic properties, Electrochim. Acta 111, 284 (2013).

[20] K. Pan, Y. Dong, C. Tian, W. Zhou, G. Tian, B. Zhao and H. Fu, TiO $2-B$ narrow nanobelt/ $\mathrm{TiO}_{2}$ nanoparticle composite photoelectrode for dye-sensitized solar cells, Electrochim. Acta 54, (2009) 7350.

[21] F. H. Bijarbooneh, Y. Zhao, Z. Q. Sun, Y. U. Heo, V. Malgras, J. H. Kim, S. X. Dou, Structurally stabilized mesoporous $\mathrm{TiO}_{2}$ nanofibres for efficient dye-sensitized solar cells, APL Mater. 1, (2013) 032106.

[22] N. T. Hieu, S. J. Baik, Y. Jun, M. Lee, O. H. Chung, J. S. Park, Electrospun coaxial titanium dioxide/carbon nanofibers for use inanodes of dye-sensitized solar cells, Electrochim. Acta 142, (2014) 144.

[23] I. D. Kim, J. M. Hong, B. H. Lee, D. Y. Kim, E. K. Jeon, D. K. Choi, D. J. Yang, Dyesensitized solar cells using network structure of electrospun $\mathrm{ZnO}$ nanofiber mats, Appl. Phys. Lett. 91, (2007) 163109.

[24] E. Hosono, S. Fujihara, I. Honma, H. Zhou, The fabrication of an upright-standing zinc oxide nanosheet for use in dye-sensitized solar cells, Adv. Mater. 17, (2005) 2091. 
[25] J. Yu, J. Fan, K. Lv, Anatase $\mathrm{TiO}_{2}$ nanosheets with exposed (001) facets: improved photoelectric conversion efficiency in dye-sensitized solar cells, Nanoscale 2, (2010) 2144.

[26] S. Ito, N. L. C. Ha, G. Rothenberger, P. Liska, P. Comte, S. M. Zakeeruddin, P. Péchy, M. K. Nazeeruddin, M. Grätzel, High-efficiency (7.2\%) flexible dye-sensitized solar cells with Timetal substrate for nanocrystalline-TiO 2 photoanode, Chem. Comm. (2006) 4004.

[27] W. Guo, X. Xue, S. Wang, C. Lin, Z. L. Wang, An integrated power pack of dye-sensitized solar cell and Li battery based on double-sided $\mathrm{TiO}_{2}$ nanotube arrays, Nano Lett. 12 (2012) 2520. [28] G. Wang, H. Wang, Y. Ling, Y. Tang, X. Yang, R. C. Fitzmorris, C. Wang, J. Z. Zhang, Y. $\mathrm{Li}$, Hydrogen-treated $\mathrm{TiO}_{2}$ nanowire arrays for photoelectrochemical water splitting, Nano Lett. $11(2011) 3026$.

[29] D. Kuang, J. Brillet, P. Chen, M. Takata, S. Uchida, H. Miura, K. Sumioka, S. M. Zakeeruddin, M. Grätzel, Application of highly ordered $\mathrm{TiO}_{2}$ nanotube arrays in flexible dyesensitized solar cells, ACS Nano 2 (2008) 1113.

[30] J. H. Lim, J. Choi, Titanium oxide nanowires originating from anodically grown nanotubes: the bamboo-splitting model, Small 3 (2007) 1504.

[31] D. P. Singh, N. Ali, Synthesis of $\mathrm{TiO}_{2}$ and $\mathrm{CuO}$ nanotubes and nanowires, Sci. Adv. Mater. $2(2010) 295$.

[32] P. Roy, S. Berger, P. Schmuki, $\mathrm{TiO}_{2}$ nanotubes: synthesis and applications, Angew. Chem. Int. Ed. 50 (2011) 2904.

[33] F. Sauvage, F. Di Fonzo, A. Li Bassi, C. S. Casari, V. Russo, G. Divitini, C. Ducati, C. E. Bottani, P. Comte, M. Graetzel, Hierarchical $\mathrm{TiO}_{2}$ photoanode for dye-sensitized solar cells, Nano Lett. 10, (2010) 2562. 
[34] S. H. Ko, D. Lee, H. W. Kang, K. H. Nam, J. Y. Yeo, S. J. Hong, C. P. Grigoropoulos, H. J. Sung, Nanoforest of hydrothermally grown hierarchical $\mathrm{ZnO}$ nanowires for a high efficiency dye-sensitized solar cell, Nano Lett. 11, (2011) 666.

[35] M. McCune, W. Zhang, Y. Deng, High efficiency dye-sensitized solar cells based on threedimensional multilayered $\mathrm{ZnO}$ nanowire arrays with "caterpillar-like" structure, Nano Lett. 12, (2012) 3656.

[36] F. Shao, J. Sun, L. Gao, S. Yang, J. Luo, Forest-like $\mathrm{TiO}_{2}$ hierarchical structures for efficient dye-sensitized solar cells, ACS Appl. Mater. Interfaces 3, (2011) 2148.

[37] J. Lin, A. Nattestad, H. Yu, Y. Bai, L. Wang, S. X. Dou, J. H. Kim, Highly connected hierarchical textured $\mathrm{TiO}_{2}$ spheres as photoanodes for dye-sensitized solar cells, J. Mater. Chem. A 2, (2014) 8902.

[38] Q. Wang, J. E. Moser, M. Grätzel, Electrochemical impedance spectroscopic analysis of dye-sensitized solar cells, J. Phys. Chem. B 109, (2005) 14945.

[39] Q. Wang, S. Ito, M. Grätzel, F. Fabregat-Santiago, I. Mora-Sero, J. Bisquert, T. Bessho, H. Imai, Characteristics of high efficiency dye-sensitized solar cells, J. Phys. Chem. B 110, (2006) 25210.

[40] C. Longo, A. F. Nogueura, M. D. Paoli, Solid-state and flexible dye-sensitized $\mathrm{TiO}_{2}$ solar cells: a study by electrochemical impedance spectroscopy, J. Phys. Chem. B 106 (2002) 5925.

[41] P. Kern, P. Sastrawan, J. Ferber, R. Stangl, J. Luther, Modeling and interpretation of electrical impedance spectra of dye solar cells operated under open-circuit conditions, Electrochim. Acta 47 (2002) 4213. 
[42] L. Han, N. Koide, Y. Chiba, A. Islam, T. Mitate, Modeling of an equivalent circcuit for dyesensitized solar cells: improvement of efficiency of dye-sensitized solar cells by reducing internal resistance, C. R. Chimie 9 (2006) 645.

[43] M. Adachi, M. Sakamoto, J. Jiu, Y. Ogata, S. Isoda, Determination of parameters of electron transport in dye-sensitized solar cells using electrochemical impedance spectroscopy, J. Phys. Chem. B 110, (2006) 13872.

[44] X. Yin, Z. Xue, L. Wang, Y. Cheng, B. Liu, High-performance plastic dye-sensitized solar cells based on low-cost commercial P25 $\mathrm{TiO}_{2}$ and organic dye, ACS Appl. Mater. Interfaces 4, (2012) 1709. 
Table 1 Photovoltaic parameters of Dyesol-T- and MHAT-based photoanodes, which were measured under air mass (AM) 1.5 global $(1.5 \mathrm{G})$ one sun illumination $\left(100 \mathrm{~mW} \mathrm{~cm}^{-2}\right)$. The active areas of the cells were $\sim 0.16 \mathrm{~cm}^{2}$ (with the mask area $0.25 \mathrm{~cm}^{2}$ ); the thickness ${ }^{\mathrm{a}}$ was $\sim 12$ $\mu \mathrm{m}$, and the data presented are the average values obtained after testing three cells and finding the standard deviation thereof.

\begin{tabular}{cccccr}
\hline Samples & $J_{\mathrm{sc}}$ & $V_{\mathrm{oc}}$ & $F F$ & $\eta$ & Amount of dye $^{\mathrm{b}}$ \\
& $\left(\mathrm{mA} \mathrm{cm}^{-2}\right)$ & $(\mathrm{V})$ & $(\%)$ & $(\%)$ & $\left(10^{-7} \mathrm{~mol} \mathrm{~cm}^{-2}\right)$ \\
& & & & & 5.0 \\
\hline MHAT & $13.2 \pm 0.5$ & $0.865 \pm 0.020$ & $68.0 \pm 2$ & $8.3 \pm 0.2$ & 3.5 \\
& & & & & \\
Dyesol-T & $11.7 \pm 0.5$ & $0.820 \pm 0.010$ & $65.0 \pm 2$ & $6.6 \pm 0.2$ &
\end{tabular}

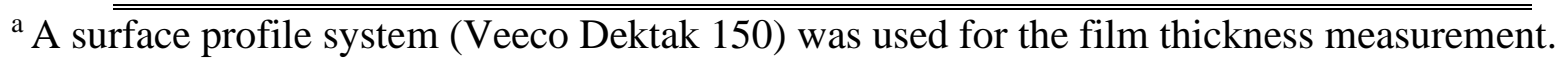

${ }^{\mathrm{b}} 0.1 \mathrm{M} \mathrm{NaOH}$ solution in mixed ethanol and water (1:1) solvent was used as the desorbent. The amount of desorbed dye was quantified by measuring its optical absorption spectrum against known concentrations. 
Table 2 Photovoltaic parameters of cells based on Dyesol-T $(12 \mu \mathrm{m}) /$ MHAT $(4 \mu \mathrm{m})$ and Dyesol$\mathrm{T}(12 \mu \mathrm{m}) /$ Dyesol-S $(4 \mu \mathrm{m})$ photoanodes measured under air mass (AM) 1.5 global (1.5G) one sun illumination $\left.(100 \mathrm{~mW} \mathrm{~cm})^{-2}\right)$. The active areas were $\sim 0.16 \mathrm{~cm}^{2}$ for all of the cells (with the mask area $0.25 \mathrm{~cm}^{2}$ ); the thickness was $\sim 16 \mu \mathrm{m}$; and the data presented are the average values obtained after testing three cells and the standard deviation thereof. EIS parameters of DyesolT/MHAT and Dyesol-T/Dyesol-S based DSCs were obtained by fitting the experimental data according to the equivalent circuit model [inset of Figure 3(c)].

\begin{tabular}{|c|c|c|c|c|c|c|c|c|c|}
\hline Samples & $\begin{array}{c}J_{\mathrm{sc}} \\
(\mathrm{mA} \\
\left.\mathrm{cm}^{-2}\right)\end{array}$ & $\begin{array}{l}V_{\mathrm{oc}} \\
(\mathrm{V})\end{array}$ & $\begin{array}{l}F F \\
(\%)\end{array}$ & $\begin{array}{c}\eta \\
(\%)\end{array}$ & $\begin{array}{l}\text { Amount } \\
\text { of dye } \\
\left(10^{-7} \mathrm{~mol}\right. \\
\left.\mathrm{cm}^{-2}\right)\end{array}$ & $\begin{array}{l}R_{\mathrm{S}} \\
(\Omega)\end{array}$ & $\begin{array}{l}R_{\mathrm{ct} 1} \\
(\Omega)\end{array}$ & $\begin{array}{r}R_{\mathrm{ct} 2} \\
(\Omega)\end{array}$ & $\begin{array}{c}C_{\mu} \\
\left(\mathrm{F} \mathrm{cm}^{-2}\right)\end{array}$ \\
\hline Dyesol-T/ & $16.2 \pm$ & $0.830 \pm$ & 73.0 & 10.3 & 6.2 & 6.9 & 9.8 & 7.0 & 0.00068 \\
\hline MHAT & 0.5 & 0.010 & \pm 2 & \pm 0.2 & & & & & \\
\hline Dyesol-T/ & $14.0 \pm$ & $0.805 \pm$ & 69.0 & 8.2 & 3.7 & 7.0 & 11.6 & 7.9 & 0.00014 \\
\hline Dyesol-S & 0.5 & 0.010 & \pm 2 & \pm 0.2 & & & & & \\
\hline
\end{tabular}




\section{Figure captions:}

Figure 1. Characterization of mesoporous hierarchical anatase $\mathrm{TiO}_{2}$ (MHAT): (a) low magnification SEM image; (b) low magnification bright-field TEM image, with the inset showing the corresponding SAED pattern; (c) enlarged TEM image; (d) ADF-STEM image of a selected sphere; (e) $\mathrm{N}_{2}$ adsorption-desorption isotherm, with the inset image showing the pore size distribution calculated from the adsorption branch of a nitrogen isotherm by the BarrettJoyner-Halenda (BJH) method; (f) XRD pattern.

Figure 2. (a) $J-V$ characteristics of Dyesol-T- and MHAT-based DSCs; the inset shows a crosssectional SEM image of the MHAT film on FTO. (b) IPCE curves of Dyesol-T-and MHATbased DSCs; the inset shows diffuse reflectance spectra of Dyesol-T, Dyesol-S, and MHAT films at $\sim 12 \mu \mathrm{m}$.

Figure 3. (a) $J-V$ characteristics. The inset shows a schematic illustration of the device structures; (b) IPCE curves; (c) Nyquist plots, with the inset showing the equivalent circuit; and (d) Bode phase plots of optimized DSCs based on Dyesol-T $(12 \mu \mathrm{m}) / \mathrm{MHAT}(4 \mu \mathrm{m})$ and Dyesol$\mathrm{T}(12 \mu \mathrm{m}) / \mathrm{Dyesol}-\mathrm{S}(4 \mu \mathrm{m})$. 

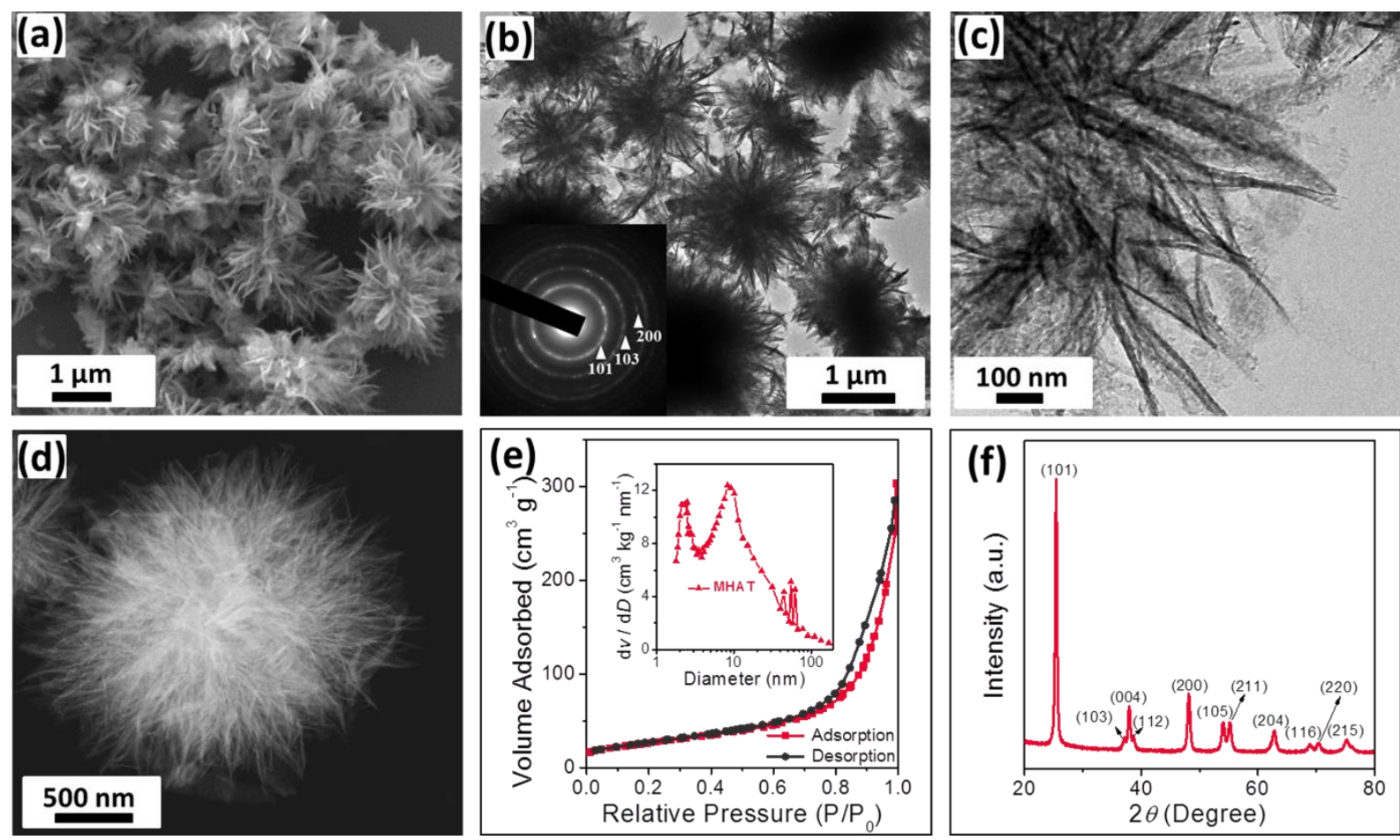

Figure 1. 

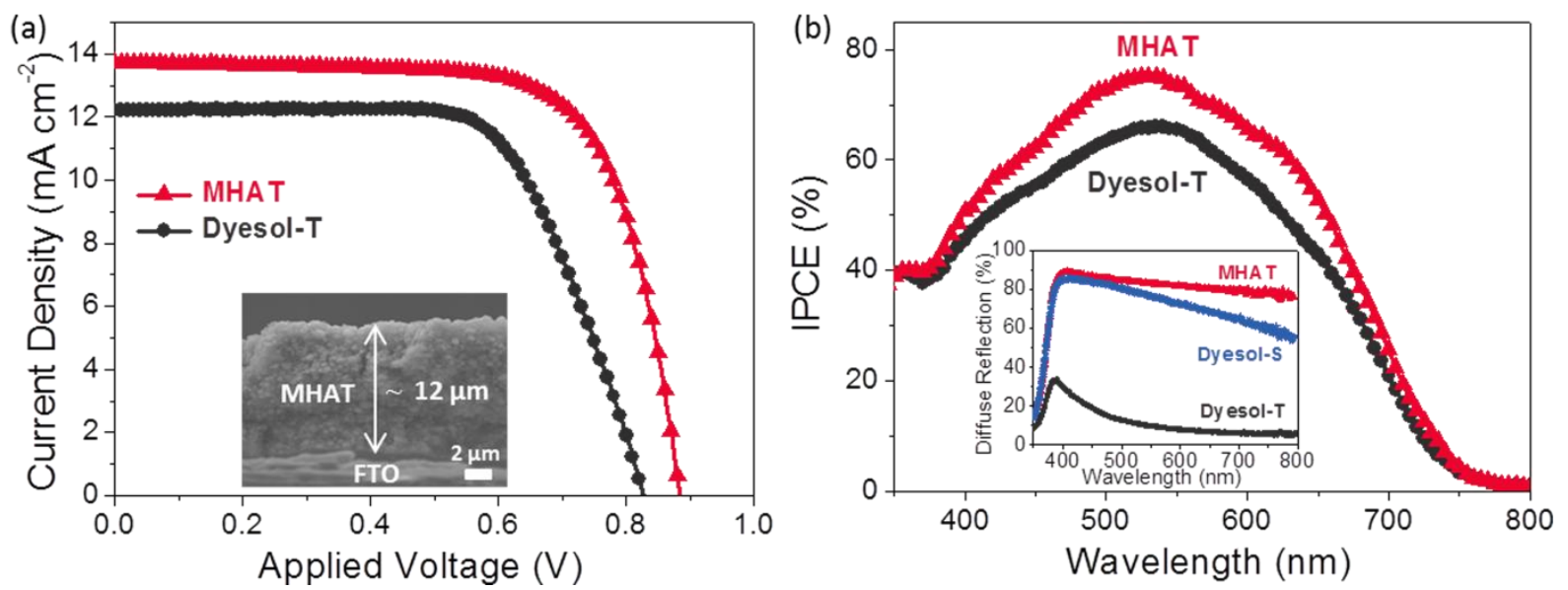

Figure 2. 

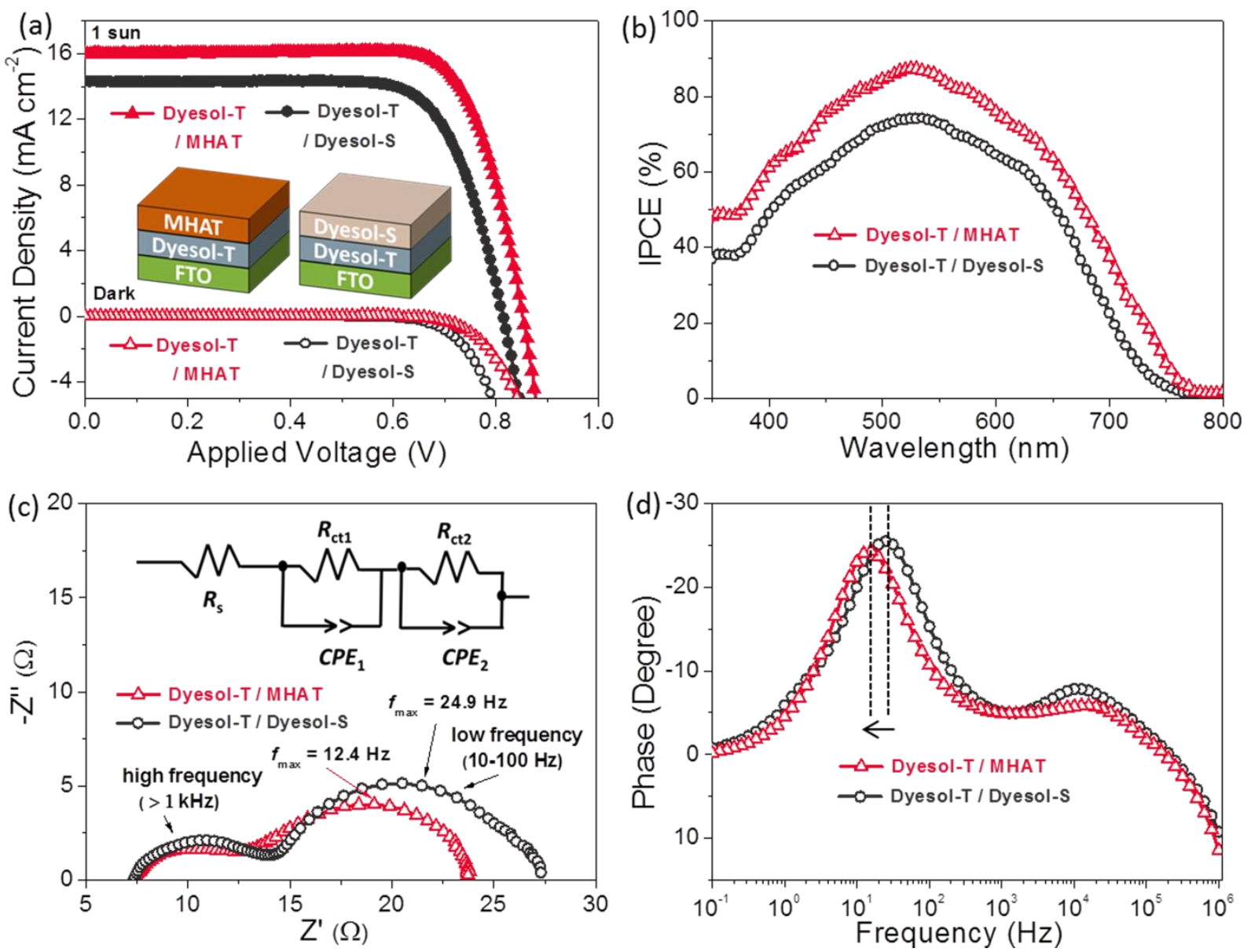

Figure 3. 